Berlach Nataliia, Doctor of Juridical Sciences, Professor, State Research Institute MIA Ukraine,

Kyiv, Ukraine,

ORCID ID 0000-0003-0132-7737

Berlach Yurii,

Candidate of Juridical Sciences,

Postgraduate, Vienna University of Economics and Business, Vienna, Austria,

ORCID ID 0000-0003-2715-802X

\title{
INTRODUCTION OF THE BEST EUROPEAN PRACTICES TO THE FUNCTIONING OF UKRAINIAN POLICE
}

The article analyses possibilities of implementation of European experience into functioning of National Police of Ukraine. The level of trust to police is reasoned as a primary criterion to evaluate the efforts and results of this authority. On the basis of statistical data, two EU-countries with the highest level of trust of citizens in police have been chosen for analysis. Emphasis is made on cooperation with ordinary citizens during fulfilment of some police functions. Based on the study of specific legal provisions and practice of their implementation, concrete steps for introduction of foreign experience in Ukraine are proposed.

Keywords: National Police of Ukraine, foreign experience, trust to police, police, cooperation with volunteers, auxiliary police, Danish police, German police.

The Universal Declaration of Human Rights proclaims in Article 3 the right of everyone to life, liberty and security of person [1]. In order to implement this fundamental human right in practice one needs a broad range of governmental and local authorities whose mutual efforts provide everybodyrs safety and protection. One of the most important roles in this process play police which originate from the will of society to prevent and counteract crimes and offences against life, freedoms and property.

Not an exclusion is National Police of Ukraine as well that was established in 2015, after reforming of internal affairs agencies. The main objectives of the new authority are to serve the society through protecting human rights and freedoms, countering crime, and facilitating public security and order [2]. Apart of that, new Department of patrol police has been created as an integral part of the whole police. Main responsibilities of the Department include among others prevention of offences, providing of public security and order, provision of traffic safety, reacting to the reports about offences [3].

Despite much effort in recent years, many domestic and international surveys show that the majority of the Ukrainian society does not have trust and confidence in own police. For instance, the results of national survey show that National Police and Department of patrol police enjoy the trust (full or partial) among respectively

DOI (Article): https://doi.org/10.36486/np.2019.305

(c) Berlach Nataliia, Berlach Yurii, 2019 
$37,9 \%$ and $37,2 \%$ of society. What is more, only ca. $6 \%$ of respondents has full trust in recently established authorities, the rest has merely partial trust therein [4]. Such results are also backed by findings of research initiated by The International Republican Institute which indicate that only $26 \%$ of Ukrainians approves the activities of police (strongly or partially), whereas only $4 \%$ has strong approval [5].

This state of things dramatically contrasts with the situation in the European Union (further - the EU) where citizens mostly do trust in their national police. According to the data of the European Commission, in the end of 2018, the average for the EU was $72 \%$ of population who trusts in police. Of course, there are significant differences within the represented countries; for instance, there are only ca. $45 \%$ of Slovaks that trust their police but more than $90 \%$ of Finns with the same attitude (sen also the Table 1 for comomaricon)

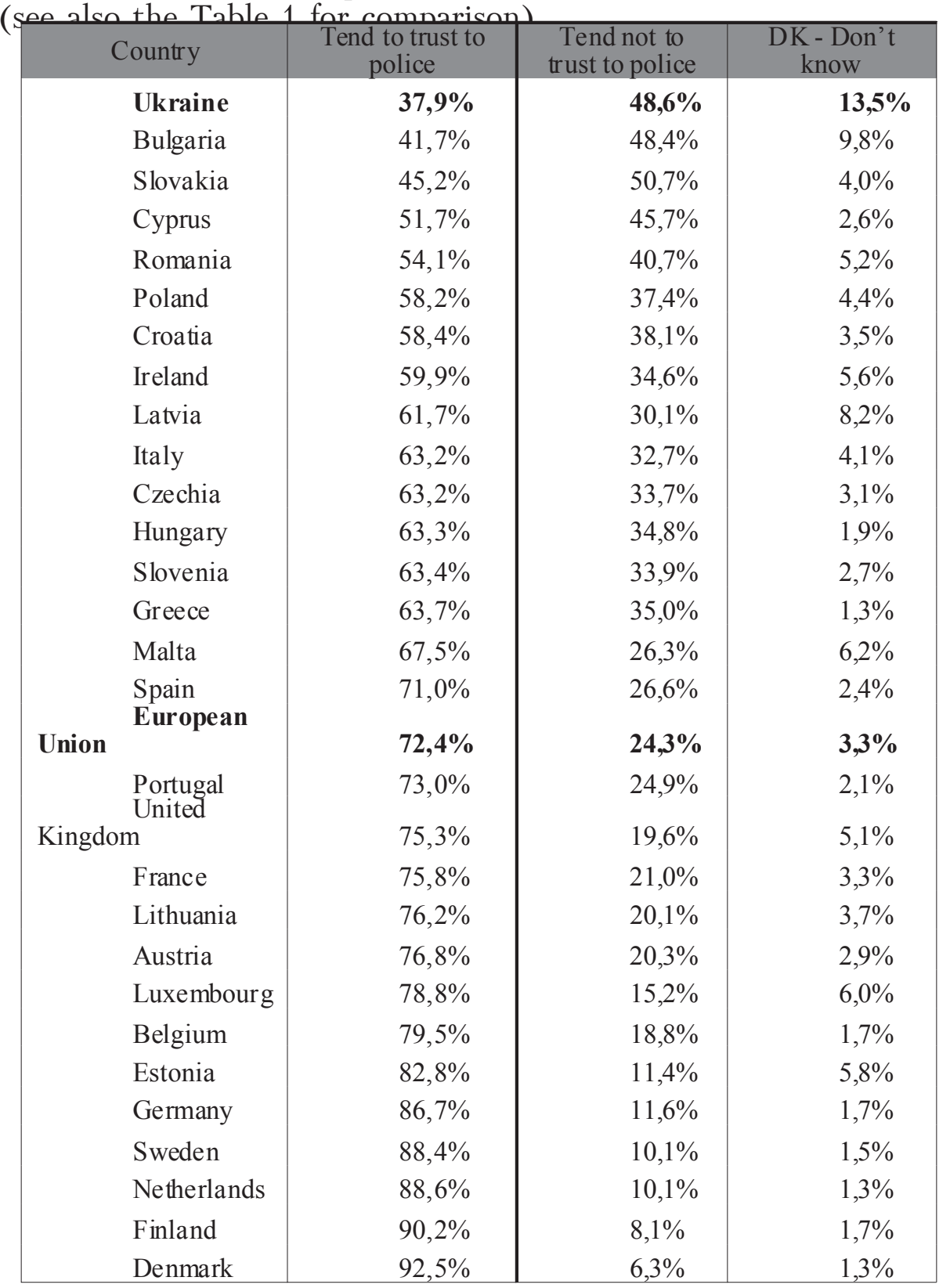

Table 1. Level of confidence in police in the EU-countries [6] and Ukraine [7]

DOI (Article): https: /doi.org/10.36486/np.2019.3.05

(c) Berlach Nataliia, Berlach Yurii, 2019 
Taking into consideration the data presented above, it is reasonable to suggest that it is of immense relevance to improve Ukrainian Police in order to serve own society in the way which reinforces the trust to this authority. One of the feasible ways to do so is to analyse foreign experience in this domain and discuss possibilities of its implementation. Only through constant and persistent improvements it is possible to achieve the objectives quoted in the specific law and provisions.

From the information stated in the Table 1 we can define the countries which are worth to consider as an example for Ukraine while improving own system of police. The reason we are convinced that the level of trust is a suitable criterion to define a choice is the fact that all governmental authorities are created by society and in order to serve this society in one or other way. And the trust of people to such authorities is the best indicator on whether or not they function well.

According to the Oxford English Dictionary, "trust" stays for firm belief in the reliability, truth, or ability of someone or something [8]. Indeed, the extent to which police is reliable, trustworthy and able to protect rights and freedoms of citizens is the most credible indicator for the successful police reform.

Therefore, the aim of this article is to analyse the functioning of police in the countries where people trust to this authority the most and to find the practices which could be successfully applied in Ukraine.

Among scientist who addressed the best European practices and/or their implementation into functioning of Ukrainian police we can quote Beck A. et al. [9], M. Caparini et al. [10], F. Coudert et al.[11], P. Lindstrцm [12], V.O. Kryvolapchuk [13], M.F. Kryshtanovich [14], S.M. Lelet [15]. Despite the thorough inquiry of both Ukrainian and foreign scholars into the problematic, we can allege that Ukrainian police problematic is not being discussed very actively among foreign scientists, even though general recommendation and proposals to Eastern European Countries in this regard are being made. Unfortunatelly, respective foreign publications devoted to Ukraine specifically do not cover the recent developments and reforms which were accomplished in last years. On the other hand, Ukrainian scholars, in spite of indeed multiple researches in this direction, do not emphasize strong enough the possibilities and ways of implementation of positive European experience into domestic practise. Moreover, it remains very often unclear, which criteria are used to designate some practice or experience as positive and useful to make Ukrainian Police better.

Therefore, we consider this research as an attempt to analyse practises of police in European countries which could be implemented in Ukraine. We use statistical data both from EU and Ukraine, scientific publications and reports, public statements of police officials, relevant legal acts, information provided at official web-sites of police authorities, etc.

We begin with analysis of Denmark as it leads the above list and has a long tradition of law enforcement bodies. Danish police consist of 14 departments which cover the whole territory of the country. The special Act on Police Activities of 2015 [16] sets out main duties, objectives, rights of this authority, and procedures to follow.

One distinctive feature of Danish police we want to address more precisely is its cooperation with citizens. And we are talking not only about collaboration while

DOI (Article): https://doi.org/10.36486/np.2019.3.05

(C) Berlach Nataliia, Berlach Yurii, 2019 
finding the reasons or backgrounds of crime, gathering statistics or implementing proposals. There are number of activities which are permanently supported by ordinary people while helping out regular police forces to provide order in public places, during large events, within border controls etc.

Such tasks are carried out by volunteers who constitute the Home Guard which is legally a part of military defence but has its own commander. The Home Guard reports to defence minister and supports authorities in their tasks. Volunteers are Danish citizens who have reached the age of 18, have Danish nationality, are suitable for service in the Home Guard, reside in the country and are worthy of the respect and trust the service requires. The country is divided into a number of district areas where special district committees are established. The committees decide on the admission of volunteers to the Home Guard.

Volunteers in the Home Guard must complete special education of 250-300 hours within the first three years of membership. Moreover, in order to remain a member of the active force, volunteers must fulfill at least 24 hours of function-related service annually. A person is accepted as a volunteer in the Home Guard by signing a contract which can, however, be terminated with a 3 months' notice.

Volunteers in the Home Guard are only subject to the rules of military criminal law, military administration and military disciplinary law during war or other extraordinary circumstances. So, as a rule, volunteers are considered as civilians and also legally treated as such.

The service in the Home Guard is generally unpaid. However, during war or other extraordinary circumstances volunteers are paid salaries. Only full-time personnel employed at the Home Guard (e.g. office workers, technicians, mechanics, etc.) gets permanent remuneration.

The requirements above and other provisions of the Law on the Home Guard [17] make it clear that activities of volunteers are strictly organized and regulated by special law as well as determined by the Minister of defence. Being a primarily military organization, the Home Guard supports Danish civil authorities, primarily police, Emergency Management Agency, etc.

There is a specified division within the Home Guard which cooperates with police within some of its activities - Police Home Guard. This division faces hundreds of Danes at sport, cultural, and music events while securing their safety and order. The most common tasks of volunteers in Police Home Guard are traffic control, borders control, but they also help police with searches and observation tasks.

It is always the police who deploy Police Home Guard, so the volunteers are always under supervision of police. The cooperation is so common that today Police Home Guard is one of the most actively used divisions of the Home Guard. There are 40 volunteer Police Home Guard companies distributed throughout Denmark [18].

We would therefore postulate that active involvement of civilians for fulfillment of some police objectives could be theoretically and practically feasible. It could be implemented into reality via cooperation with military forces of even with civilian.

Ukraine already has a special law which regulates this domain [19], but it prescribes grounding of a public association by citizens which than can cooperate with police. In our point of view, the prime role should be played by National Police

DOI (Article): https://doi.org/10.36486/np.2019.3.05

(C) Berlach Nataliia, Berlach Yurii, 2019 
since it has the largest interest in the whole process (saving of personnel expenditures, improvement of efficiency, increasing of trust, etc.). Moreover, centralized approach to the issue would allow pursuing a state policy more consistently and achieving better results, since police would apply clear requirements, procedures and could select candidates which are really needed. It would also encourage those who neither belong to any public association not want to join one.

But what is the most important, engaging of civilians could significantly raise the trust of society to police and also provide better social control over it. Police would also win in such situation since its costs for personnel would decrease, while acceptance among population rise.

Other countries which demonstrate high levels of trust in police have many similarities with Denmark. For example - Norway [20], Sweden, Finland, Netherlands all demonstrate relatively small number of inhabitants, mostly homogeneous population, high GDP per capita and established institutional systems. Experts postulate that "people in the Nordic countries are unusually trusting. A much higher proportion of the population than in other European countries agree with the following statement: "Most people can be trusted". The Nordic countries are also known to have little corruption and systems ensuring everyone an education and other public benefits and services [21]".

We would therefore continue our analysis with a country which is more diverse and populous and whose experience could be implemented in Ukraine. A good example for it is Germany which has comparable size, more diversified demographic structure and comparable legal system.

German police authorities also have a possibility to involve civilians as assistants while fulfilling some of their functions. Provisions of the special "Law on Federal Police" (Germ. - "Gesetz sber die Bundespolizei") [22] defines peculiarities of auxiliary police officers (Germ. - "Hilfspolizeibeamte"). According to the provision of the mentioned law, Federal Police may appoint suitable persons to perform certain tasks, such as:

- surveillance of borders and control of international traffic;

- defence against dangers on railway facilities;

- protection against attacks on the safety of air traffic;

- protection of constitutional organs of the Federal Government, securing facilities of the Federal Police.

Such an appointment may take place when there is a need for auxiliary police officers. Nevertheless, such an order can be revoked at any time which means that auxiliary police officers do not enjoy the secured status of professional police and can be involved (and dismissed) ad-hoc.

Further, the police-assistants have the powers of Federal Police officers within the scope of the tasks entrusted to them. However, they are not empowered to apply direct coercion (using of firearms [23]).

Due to the federal division of the country, German police is also divided into federal (central) and state (local) levels. All states (Germ. - "Bundeslдnder") also have own police which mostly takes care of public order, preventing the general or individual dangers to public safety or public order, as it is the case for Bavarian State Police [24].

DOI (Article): https://doi.org/10.36486/np.2019.3.05

(c) Berlach Nataliia, Berlach Yurii, 2019

Issue 3(4.5) 2019

http://naukaipravoohorona.com/ 
All States have own legislation concerning police matters and therefore can apply their own rules which can vary from state to state. For example, in Lower Saxony police authorities can appoint auxiliary police officers and transfer them police functions. The auxiliary police officers are also entitled to exercise police powers in the context of the assigned tasks [25]. Such appointments include mostly tasks where the exercising of coercion is not necessary. The effectiveness of auxiliary police had been proved also in practice, for example within escorting of heavy and outsized cargos, objects security which should be carried out by regular police. The result of such deployment was releasing of police resources for more critical tasks with higher priority. For escort, for example, private firms are being hired and accordingly empowered with necessary rights. Applicants who suit the requirements of police should also underego a relatively short training course (not longer than a week) in order to begin their service as auxiliary police [26].

Another aspect of state (local) police in Germany is its direct cooperation with civil population in fulfilling own tasks. This task lies also in domain of states and therefore is regulated by state (and not federal) legislation. As an example, we would consider the experience of Bavaria.

There is a special law "On the Security Guard in Bavaria" which includes main provisions, requirements, rights, duties and procedures relating the Security Guard (Germ. - "Sicherheitswacht") [27]. Through this institution, citizens participate in the maintenance of public safety and order, such activities are considered as a honorary i.e. voluntary service. The members of the Security Guard assist the police in their duties, in particular concerning counteraction to street crime.

As such, volunteers do not possess much specific rights above all citizens i.e. they can, as everyone else, prevent witnessed crime, interfere in a conflict to resolve it, halt a supposed criminal, provide help, call police, make a notice, etc. Orders and other measures that interfere with the rights of others may only be made by members of the Security Guard if they are specifically authorized by law.

More specifically, within the service, they may question people about their perception to actual events or persons, if it is to be assumed that they can provide relevant information. Moreover, the members of Security Guard are authorized to identify the person which is considered as a source of danger in order to avert such danger. They may, in particular, halt the person, ask them for their personal details, request that they show any identity documents for examination and remove any items of clothing or objects that prevent their identification. A person may be held until the arrival of the police. Additionally, the members of Security Guard can temporarily remove a person from a location to ward off a danger.

The members of Security Guard wear the clothing provided by police department during the service. They also do not carry any firearms, punching or cutting weapon.

Security Guard consists of volunteers who stay in a special public service of the State of Bavaria. They are appointed at their own request by police headquarter (superior authority over local police departments) for the service in a specific police department, which is normally situated nearby their place of residence. The appointment is revocable at any time by the delivery of a record and can be limited in time, so it is quite simple to dismiss a volunteer when he misconducts or is not able to fulfill his

DOI (Article): https://doi.org/10.364.86/np.2019.3.05

(c) Berlach Nataliia, Berlach Yurii, 2019 
duties properly. The members of Security Guard are subject to the instructions of the police authorities and therefore are obliged to follow them.

Finally, volunteers receive lump-sum compensation for their expenses in accordance with administrative regulations of the respective Ministry of internal affairs, sport and integration. It means that the State does not bear any social insurance and additional costs and thus uses funds more efficiently.

As we can see, involvement of civilians to the cooperation with police is also feasible in countries comparable with Ukraine in size, population, demographic structure and legal system. What is more, the application of the such practises has been proved as very successful since society directly interact with police from the both sides of the service, the patrolling becomes more effective, level of trust in police rises.

Making a conclusion, we can suggest that improving of Ukrainian Police should proceed alongside with the improvement of people's trust in this institution. Therefore, it seems reasoned to implement practices of those countries which demonstrate high achievements in this respect. Both in small (as Denmark) and large (as Germany) EU countries which enjoy high level of trust to police it is possible to involve ordinary citizens to fulfilment of originally police duties such as patrolling, traffic control, searches and observation operation, providing of security during mass events, etc. Our findings show that such practices definitely enhance efficiency of police, foster cooperation within society, let the trust to police rise and, not in the least, spare both financial and personnel resources. Even though Ukraine already has special legislation in this sphere, proposed amendments would definitely allow using of already proved mechanisms of cooperation with citizens to reach better protection of proclaimed human rights and freedoms.

\section{REFERENCES}

1. The Universal Declaration of Human Rights of 1948, General Assembly resolution 217A. Retrieved from: https://www.un.org/en/universal-declaration-human-rights/ (date of application: 19.04.2019) [in English].

2. The Law of Ukraine on National police of 02.07.2015 № 580-VIII. Retrieved from: https:// zakon.rada.gov.ua/laws/show/580-19 (date of application: 09.02.2019) [in Ukrainian]

3. Provision on Department of patrol police, adopted by Decree of National police of Ukraine of 06.11.2015 № 73 Retrieved from: http://patrol.police.gov.ua/wp-content/uploads/2016/03/Polozhennya_DPP_zi_zminamy_vid_31_10_16.pdf (date of application: 09.02.2019) [in Ukrainian].

4. Razumkov Centre (2019) Level of trust to social institutions and electoral orientations of the citizens of Ukraine. Sociological Study of 27.03.2019. Retrieved from: http://razumkov.org.ua/ napriamky/sotsiologichni-doslidzhennia/riven-doviry-do-suspilnykh-instytutiv-ta-elektoralni-oriientatsiigromadian-ukrainy-2 (date of application: 09.02.2019) [in Ukrainian].

5.International Republican Institute (2018) Public Opinion Survey of Residents of Ukraine. Conducted from 26.05. to 10.06.2018. Retrieved from: http://www.iri.org/sites/default/files/ june_2018_national_survey.pdf [20.04.2019]

6. European Commission (2019) Eurobarometer Interactive. Trust in institutions. The police. Retrieved from: http://ec.europa.eu/commfrontoffice/publicopinion/index.cfm/Chart/getChart/ chartType/gridChart//themeKy/18/groupKy/88/savFile/201 (date of application: 09.02.2019) [in English].

7. Razumkov Centre (2019) Level of trust to social institutions and electoral orientations of the citizens of Ukraine. Sociological Study of 27.04.2019. Retrieved from: http://razumkov.org.ua/ napriamky/sotsiologichni-doslidzhennia/riven-doviry-do-suspilnykh-instytutiv-ta-elektoralni-oriientatsiigromadian-ukrainy-2 (date of application: 19.04.2019) [in Ukrainian].

DOI (Article): https://doi.org/10.36486/np.2019.3.05

(c) Berlach Nataliia, Berlach Yurii, 2019

Issue 3(4.5) 2019

http://naukaipravoohorona.com/ 
8. Oxford English Dictionary online (2019) Retrieved from: https://en.oxforddictionaries.com/ definition/trust [date of application: 20.04.2019] [in English].

9. Caparini M., Marenin O. (2004) Transforming the police in Central and Eastern Europe. In Caparini M., Marenin O. (Eds.), Transforming the police in Central and Eastern Europe: Process and Progress p. 8-25. Munster [in German].

10. Beck A., Povolotskyi A., Yarmysh A. (2004) Reform of the Militia in Ukraine. In Caparini M., Marenin O. (Eds.), Transforming the police in Central and Eastern Europe: Process and Progress (P. 278-287). Munster [in English].

11. Couderta F., Butinb D., Le Metayerc D. (2015) Body-worn cameras for police accountability: Opportunities and risks. Computer Law \& Security Review, 31(6), P. 749-762. doi: 10.1016/j.clsr. 2015.09.002 [in English].

12. Lindstrom P. (2015) Police and crime in rural and small Swedish municipalities. Journal of Rural Studies, 39, P. 271-277. doi:10.1016/j.jrurstud.2014.12.004 [in English].

13. Krivolapchuk V.O. (2014) General directions of change of the police development paradigm in XXI century (European experience). Law and state governance: a collection of scientific works, 4(17), p. 139-143 [in Ukrainian].

14. Kryshtanovich M.F. (2015) European experience of public administration of police bodies and possibilities of its application in Ukraine. Current problems of public administration, 1, p. 287293. Retrieved from: http://nbuv.gov.ua/UJRN/apdy_2015_1_42 (date of application: 09.02.2019) [in Ukrainian].

15. Lelet S.M. (2016) Experience of European Union countries on administrative and legal regulation of police management and its application in Ukraine. Nauka I pravookhorona. P. 111-115. Retrieved from: http://nbuv.gov.ua/UJRN/Nip_2016_1_17 (date of application: 09.02.2019) [in Ukrainian].

16. Law on Police Activities (the Police Act), LBK no. 956 of 20/08/2015. Retrieved from: https://www.retsinformation.dk/Forms/R0710.aspx?id=143225 (date of application: 23.04.2019) [in Danish].

17. Law on the Home Guard, LBK no 198 of 09.02.2007. Retrieved from: https:// www.retsinformation.dk/Forms/R0710.aspx?id=6487\#K1 (date of application: 23.04.2019) [in Danish].

18. Danish Home Guard (2019) Police Home Guard. Retrieved from: https://www.hjv.dk/oe/ POHVKHAR/om-os/Sider/default.aspx (date of application: 23.04.2019) [in Danish].

19. On the participation of citizens in the protection of public order and the state border: the Law of Ukraine of 22.06.2000 № 1835-III. Retrieved from: https://zakon.rada.gov.ua/laws/show/ 1835-14 (date of application: 09.02.2019) [in Ukrainian].

20. Ortiz-Ospina E., Roser M. (2019) Trust. Retrieved from: https://ourworldindata.org/trust (date of application: 23.04.2019) [in English].

21. Kvittingen I. (2017) Why do the Nordics trust one another? Retrieved from: https:// sciencenorway.no/forskningno-norway-social-relations/why-do-the-nordics-trust-one-another/1444626 [date of application: 09.02.2019] [in German].

22. Law on federal police of 19.10.1994. Retrieved from: https://www.gesetze-im-internet.de/ bgsg_1994/BJNR297900994.html (date of application: 09.02.2019) [in German].

23. Law on direct coercion in the exercise of official authority by federal law enforcement officers of 10.03.1961. Retrieved from: https://www.gesetze-im-internet.de/uzwg/BJNR001650961.html (date of application: 09.02.2019) [in German].

24. Law on the tasks and powers of the Bavarian State Police of 14.09.1990. Retrieved from: https://www.gesetze-bayern.de/Content/Document/BayPAG-1 (date of application: 09.02.2019) [in German].

25. Lower Saxony Law on police and order authorities of 01.01.2005. Retrieved from: http:// www.nds-voris.de/jportal/?quelle $=$ jlink \&query $=\mathrm{SOG}+\mathrm{ND} \& \mathrm{psml}=$ bsvorisprod.psml\&max $=$ true\&aiz $=$ true\#jlr-SOGNDV2P1 (date of application: 09.02.2019) [in German].

26. Political Journal of Lower Saxony (2018) Interior Ministry stakes increasingly on auxiliary police in the future. Retrieved from: https://www.rundblick-niedersachsen.de/innenministeriumsetzt-kuenftig-verstaerkt-auf-hilfspolizisten (date of application: 09.02.2019) [in German].

27. Law on the Security Guard in Bavaria of 28.04.1997. Retrieved from: https://www.gesetzebayern.de/Content/Document/BaySWG/true (date of application: 09.02.2019) [in German].

DOI (Article): https://doi.org/10.36486/np.2019.3.05

(c) Berlach Nataliia, Berlach Yurii, 2019 
Берлач Наталія Анатоліївна доктор юридичних наук, професор, провідний науковий співробітник ДНДІ МВС України, м. Київ, Україна, ORCID ID 0000-0003-0132-7737

Берлач Юрій Миколайович кандидат юридичних наук, здобувач Віденьського університету економіки та бізнесу, м. Відень, Республіка Австрія ORCID ID 0000-0003-2715-802X

\section{УПРОВАДЖЕННЯ КРАЩИХ ЄВРОПЕЙСЬКИХ ПРАКТИК У ДІЯЛЬНІСТЬ УКРАЇНСЬКОЇ ПОЛІЦІї}

Стаття присвячена розгляду можливостей запозичення Україною досвіду функціонування поліції країн СС. Як критерій оцінки роботи органів поліції обрано рівень довіри громадян до них. Наголошено, що наразі Національна поліція України та Департамент патрульної поліції зокрема має недостатній рівень довіри серед населення, якщо порівнювати його з аналогіними показниками країн СС.

Як країни, варті детального розгляду, обрано Данію, яка демонструє найвищий рівень довіри до поліцейських (більше 90 \%), а також Німеччину, яка також показує високі показники у цій сфері, але окрім того, має більше спільних рис 3 Україною (територія, кількість та структура населення, правова система тощо.). Взято до уваги статистичні дані, відповідні нормативно-правові акти обох країн, практику їх застосування, а також вітчизняне законодавство в аналізованій сфері.

Наголошено, що робота поліції як у Данії, так і в Німеччині широко доповнюється участю добровольців, які виконують деякі функції поліцейських. Серед таких функцій виділено патрулювання, забезпечення громадського порядку під час масових заходів, надання допомоги потерпілим, виявлення та попередження злочинів, участь у операціях з ведення спостереження чи навіть пошуку злочинців, участь у регулювання дорожнього руху тощо. Відзначено, що добровольці не є поліцейськими і користуються загальними правами кожного громадянина, втім, їм надано певні додаткові повноваження (перевірка документів, заборона знаходитися в певному місці тощо).

Застосування такої взаємодії підвищує довіру суспільства до поліції, вивільняє її фінансові та людські ресурси для виконання більш критичних завдань, а тому в цілому робить її функціонування ефективнішим.

Розглянуто українське законодавство в аналізованій сфері, яке, тим не менш, вимагає деяких змін для більш дієвої взаємодії громадян і поліції. Зокрема, наголошено, що добровольці мають співпрацювати з поліцією безпосередньо, а не через громадські організації чи установи, де працюють громадяни. У запро-

DOI (Article): https://doi.org/10.36486/np.2019.3.05

(c) Berlach Nataliia, Berlach Yurii, 2019

Issue 3(45) 2019

http://naukaipravoohorona.com/ 
DOI (Issue): https://doi.org/10.36486/np.2019.3

Issue $3(4.5) 2019$

вадженні насправді діючої системи взаємодії та співпраці з суспільством має, в першу чергу, бути зацікавлена сама Національна поліція Україні. Адже саме цей орган таким чином покращує ефективність своєї роботи, підвищує рівень довіри до себе та може виділити більше ресурсів для завдань вищого рівня складності.

Ключові слова: Національна поліція України, зарубіжний досвід, довіра до поліції, поліція, співпраця з добровольцями, допоміжна поліція, поліція Данії, поліція Німеччини.

Отримано 28.08.2019 